\section{FINANCING GERMANIC MILITARY CAMPAIGNS WITH EASTERN DENARII}

\begin{abstract}
In 2001, Duncan-Jones assessed Howgego's work on the mobility of Septimius Severus' Eastern denarii on the basis of hoards in Britain. Duncan-Jones argues that the increased presence of Severus' Eastern denarii in hoards over time was the manifestation of Gresham's Law, while Howgego interprets the evidence as an indicator for some sort of supply/arrival. In 2016, Hellings tested these two interpretations by assessing hoards in Roman Germany to determine the presence of Severus' Eastern denarii struck between AD 193 and 196/7. The evidence produces a radically different hoarding pattern and several explanations are suggested. This paper seeks to introduce the find pattern of non-hoarded Eastern denarii in Germany in order to reassess their function, purpose, and possible ties to historical events.
\end{abstract}

Keywords: Eastern denarii, German limes, circulation, hoards, coin finds.

rom the start of the third-century, the advent of regular decentralized coin production provides numismatists with a useful opportunity to examine the dissemination of coins Empire-wide. As Howgego has demonstrated, however, the research benefits of decentralized coin production are obscured through the debasement of silver coinage. The debasement affects the possible geographical dissemination of silver coins and therefore restricts any assessment of Empire-wide integration as manifested through circulation patterns. ${ }^{1}$ Correspondingly, bronze coinage, which is generally free from the problem of debasement, does not usually travel great distances through coin drift. Consequently, coins struck during the reign of Septimius Severus present a valuable occasion, one between routine decentralized production and severe continuous debasement, to consider the movement of coin across the Empire and its implications.
Benjamin D. R. Hellings

Yale University

benjamin.hellings@yale.edu

DOI: $10.14795 /$ j.v7i1_SI.487

ISSN $2360-266 \mathrm{X}$

ISSN-L 2360 - 266X

\footnotetext{
${ }^{1}$ HOWGEGO 1996, 222-223.
} 
This paper seeks to assess the movement of Eastern denarii struck under Septimius Severus by considering hoards together with non-hoarded coin finds in Germany so as to determine their function, purpose, and possible ties to historical events.

\section{THE DATA AND COINS}

Since no study reliant upon coin finds can ever hope to be fully up-to-date, it is important to note finds for the study region are collected from Die Fundmünzen der römischen Zeit volumes where the recorded coins, when possible, were accompanied primarily with RIC attributions. ${ }^{2}$ The 'Eastern' mints used in this study, however, require some explanation. RIC attributes coins struck during Severus' reign to three main mints (excluding 'uncertain Eastern Mint'). Alexandria struck coins early during Severus' reign with its latest coin dated to $\mathrm{AD} 195 .^{3}$ Using these coins to study interregional movement is problematic for two reasons. First, Alexandria did not produce coins for a long period and furthermore, it may have only produced these limited quantities (if the RIC rarity ratings are reliable). ${ }^{4}$ Second, Howgego has observed that catalogers have often misidentified coins as Alexandrian issues. ${ }^{5}$ This study has therefore omitted Alexandrian coins from consideration. The other two Eastern mints, Laodicea ad Mare and Emesa, produced coins for a longer period. The mint at Emesa appears to have run parallel to that of Laodicea during its early period and seems to have closed in AD 196. Laodicea ad Mare operated until AD 202 but has two main phases. The first, 'Old Style' coin, ends its production period in AD 196/7, which is followed by 'New Style' coin that was produced until AD 202. The mint at Rome also had similar phasing, however 'Old Style' coinage continued to be struck through until AD 198. ${ }^{6}$ Moreover, Duncan-Jones has noted,

\footnotetext{
2 FMRD.

${ }^{3}$ MATTINGLY/SYDENHAM 1936, 64.

4 See on RIC rarity for aurei: HELLINGS 2018, 402.

5 HOWGEGO 1996, 220.

6 HOWGEGO 1996, 220.
}

on the basis of Reka Devnia, that denarius production appears to have been largely concentrated at Rome after AD 196. ${ }^{7}$ In order to properly study the movement of Eastern denarii, it follows that a similar dataset must be utilized, which therefore only permits consideration of coins struck at Rome, Emesa, and Laodicea ad Mare between AD 193 and 196/7. Whether coins from the two Eastern mints should be regarded as being struck at Antioch instead is inconsequential for the present study since individual mints are not being considered. ${ }^{8}$

Hoards offer one of the most valuable points of assessment as they can trace the mixing of coin over time. There are, of course, several limitations to bear in mind when using hoards to determine the circulating coin pool. For the purposes of this paper, it has been assumed that hoards offer a fair representation of the currency circulating at the time of its deposition (TPQ) atits deposition location. The first goal is to establish the circulation pattern of Severus' Eastern denarii struck between AD 193 and $196 / 7$ by comparing their proportion in hoards to denarii contemporaneously struck at Rome. This paper also considers the significant number of non-hoarded (single) finds of Severus' Eastern denarii in the studyregion since these may further shed light onto the established hoard pattern and are a better reflection of the overall geographic extent of the circulation pool.

\section{THE HOARD EVIDENCE}

In Roman Germany, a total of 38 hoards have been identified with denarii struck in the East between AD 193 and 196/7, however, not all of these could be utilized for the present study. An initial minimum threshold of 20 denarii struck AD 193-196/7 (at Rome and/ or 'East') was enforced in order to establish a meaningful pattern with limited statistical

\footnotetext{
DUNCAN-JONES 1994, 137-138, esp. Table 9.13. Testing the reliability of Reka Devnia as a proxy for relative denarius production during the reigns of Nerva and Trajan: HELLINGS/SPOERRI BUTCHER 2017.

8 BUTCHER 2004, 41-42, 98-108
} 


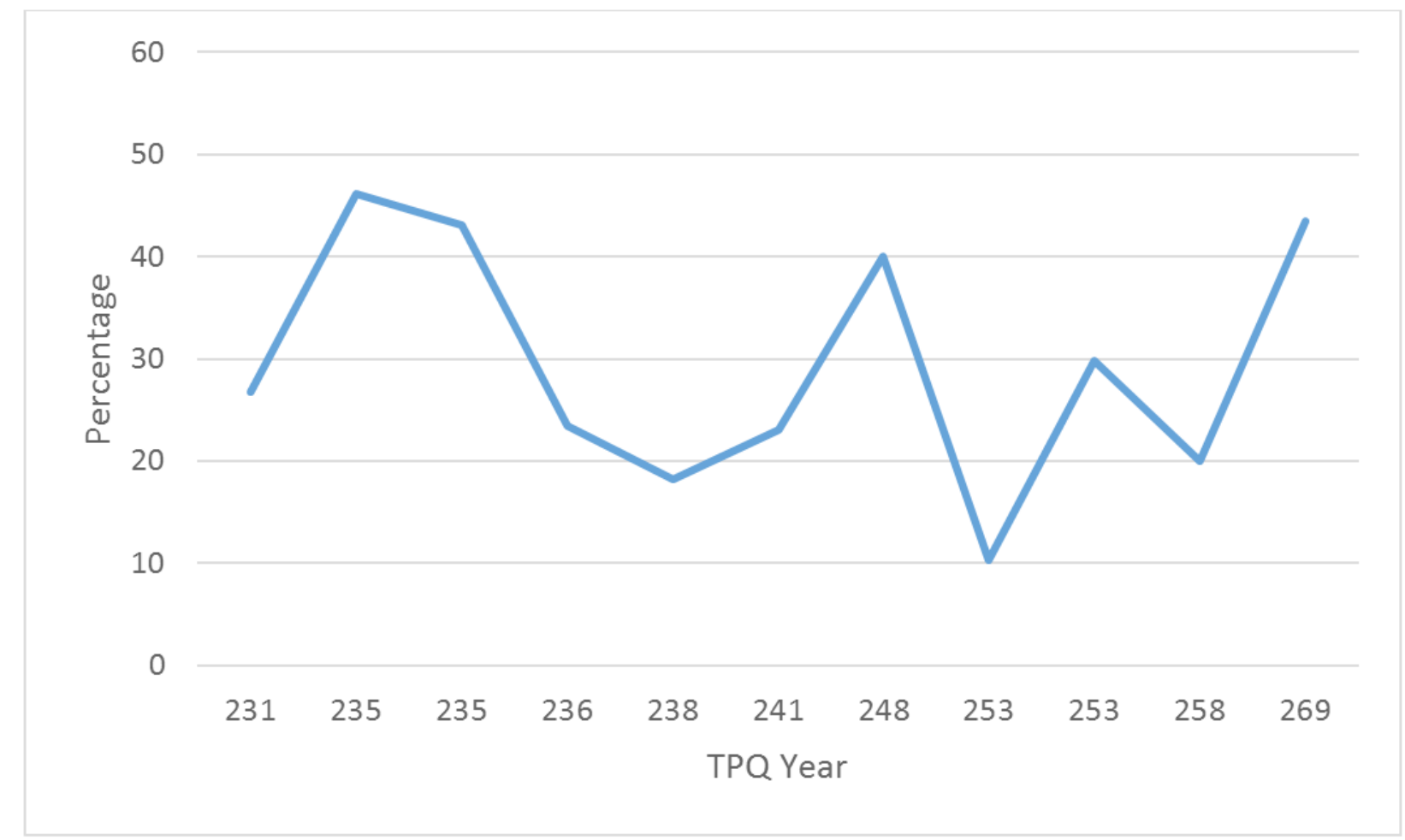

Figure 1. Eastern denarii as a percentage of denarii struck AD 193-196/7 found in hoards from Roman Germany with a minimum of 20 denarii struck AD 193-196/7, by TPQ

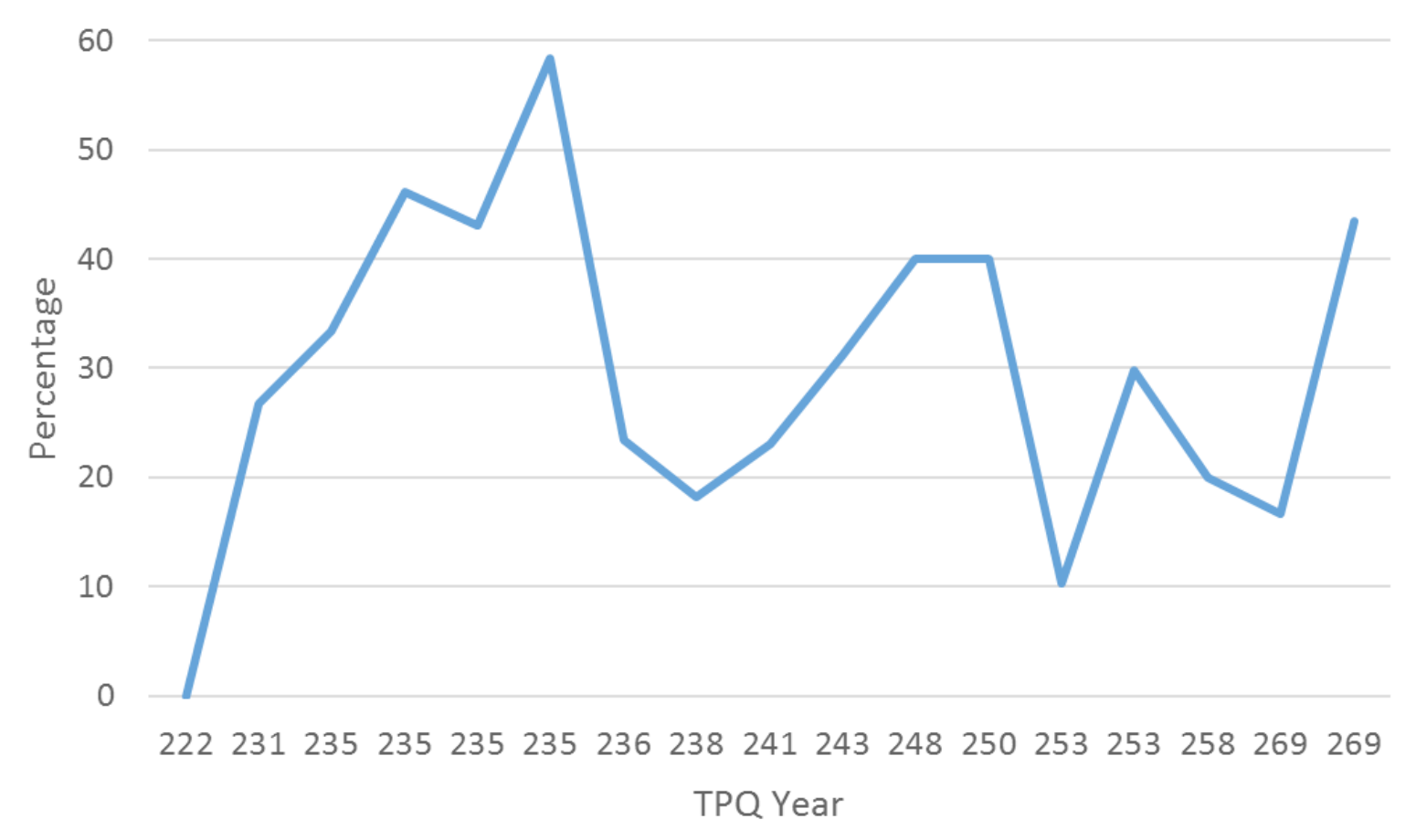

Figure 2a. Eastern denarii as a percentage of denarii struck AD 193-196/7 found in hoards from Roman Germany with a minimum of 10 denarii struck AD 193-196/7, by TPQ

distortion. The same minimum was also $\vdots$ the two regions. ${ }^{9}$ This resulted with 11 hoards applied by Howgego to British hoard data $\vdots$ in Roman Germany available for initial allowing a like-for-like comparison between $\vdots$ consideration. The fluctuation of Eastern ${ }^{9}$ HOWGEGO 2002, 341. 


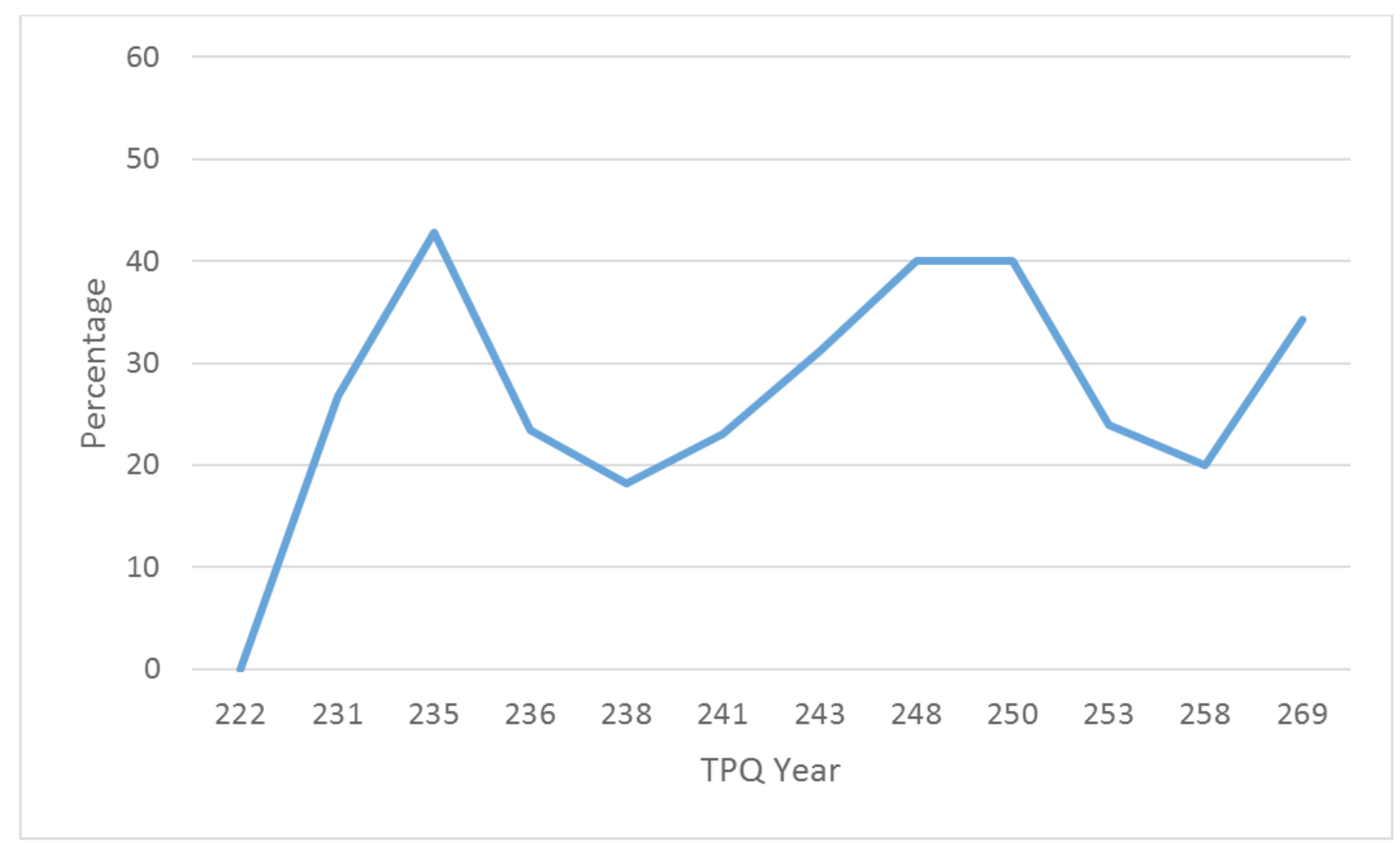

Figure 2b. Eastern denarii as a percentage of denarii struck AD 193-196/7 found in hoards from Roman Germany with a minimum of 10 denarii struck AD 193-196/7, by TPQ (hoards merged)

denarii as a percentage of all denarii struck $\mathrm{AD}$ 193-196/7 by TPQ date reveals two hoarding peaks. The first peak occurs AD 235 and the second around AD 248-253 (Figure 1).

Given the large number of hoards with Eastern denarii it is worth testing whether lowering the minimum threshold to hoards with 10 denarii struck in AD 193196/7 produces the same result. As the sample size increases to 17 hoards, a similar overall pattern is established but with some additional statistical noise (Figure 2a). If hoards closing in the same year are merged some of noise is smoothed and analysis is simplified (Figure $2 \mathrm{~b}$ ), allowing us to confirm our initial observation of two hoarding peaks of Eastern denarii, separated by a 10 to 15 year period.

The hoarding pattern established requires some clarification for two standout data points (Figure 2a). The first is the unexpectedly low number of Eastern denarii in one of the hoards closing in AD 253 during a 'peak' period of these coins in hoards. This low data point, during the second peak hoarding period of Eastern denarii (AD 248-253) stems from hoard FMRD 3, 1082
(Appendix 1, no. 13). The distance of this hoard from the limes may explain why it has a lower number of Eastern denarii. The unexpected peak, dated to $\mathrm{AD} 269$, also stems from a peculiar hoard (FMRD 4.1, 1164 - Appendix 1, no. 17). This hoard, from Mainz, derives its (late) deposition date from three undated coins attributed to the reign of Postumus applying the old RIC dating scheme. The hoard also has a complex history but even these two aspects do not fully explain its deviation from the overall pattern observed. An explanation may be that Mainz was a site with significant quantities of these coins (see below for confirmation by nonhoarded finds) and therefore remained slightly longer in circulation.

Understanding the peaks and troughs of Eastern denarii in hoards is important if we want to come to terms with their function, purpose, and possible ties to historical events. In this context, it may be useful to turn to other regions where significant quantities have been recorded to the coin level. Britain provides a useful neighboring region for comparison where both Howgego and Duncan-Jones have debated the implication of 


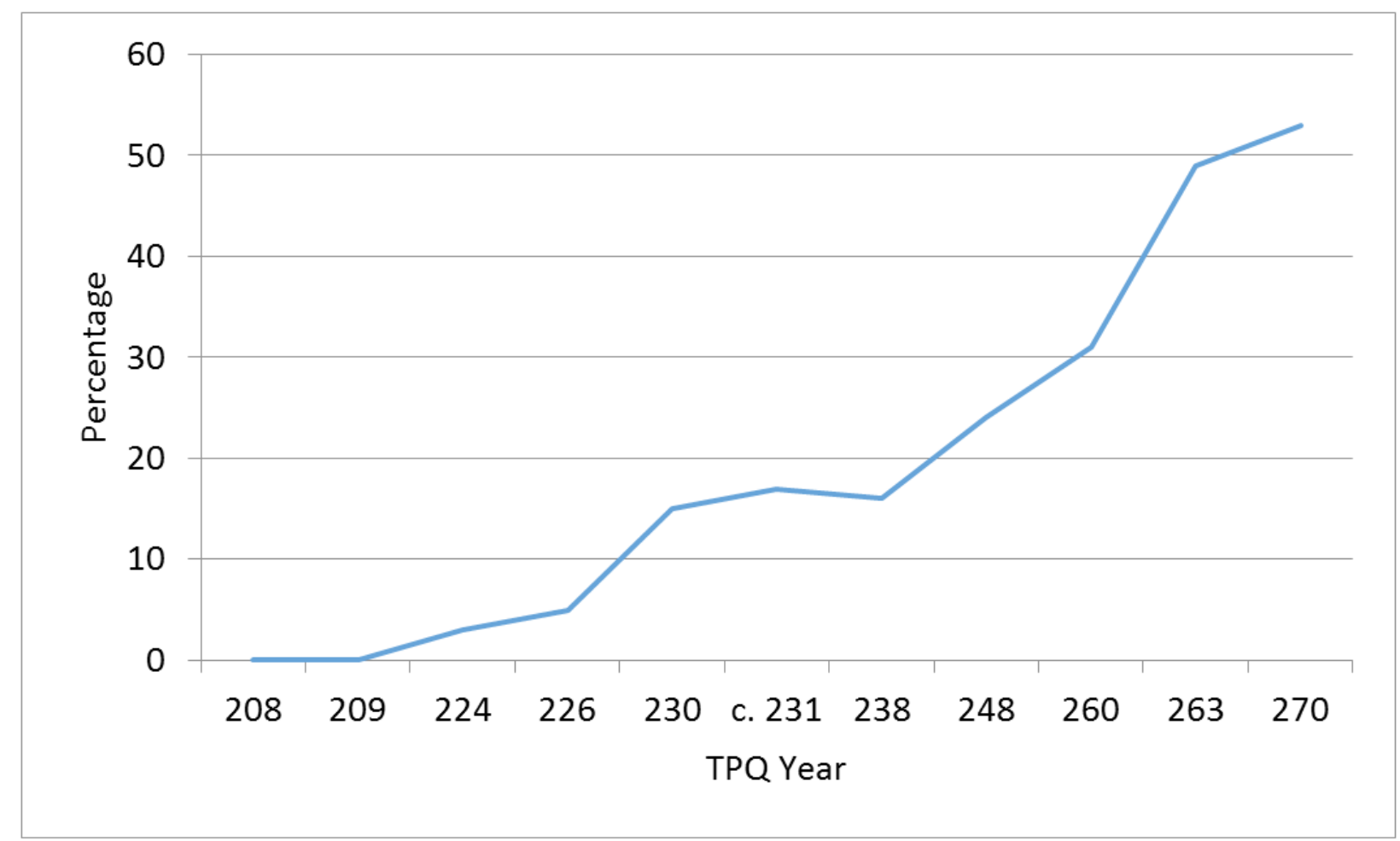

Figure 3. Eastern denarii as a percentage of denarii struck AD 193-196/7 found in hoards from Roman Britain with a minimum of 20 denarii struck AD 193-196/7, by TPQ ${ }^{10}$

the increase of Eastern denarii in hoards over time (Figure 3). Duncan-Jones interpreted the hoards as a manifestation of Gresham's Law. ${ }^{11}$ The different hoarding patterns between Britain and Germany, and in particular the fluctuation of Eastern denarii in hoards in Germany, demonstrates the unlikelihood for Gresham's Law as an explanation. If we were to consider Gresham's Law as the explanation, following Duncan-Jones, hoards in Britain exhibit a preference towards 'Rome' denarii while the unusual fluctuation in Germany appears to demonstrate indifference or even partiality towards 'Eastern' denarii. Different mechanisms, motivations, quantities of supply and access to a particular type or groups of coinage can explain the different patterns observed in Britain and Germany. ${ }^{12}$

\section{THE NON-HOARDED EVIDENCE}

Although hoards provide a useful lens to study the mixing of coins over time by their very nature they are selective; selective in

\footnotetext{
10 Data: HOWGEGO 2002, 341.

11 DUNCAN-JONES 2001; DUNCAN-JONES 2002.

12 HOWGEGO 1996; HOWGEGO 2002.
}

the sense that their contents were regarded worthy saving for one reason or another as well as selective for their non-recovery. Using nonhoarded coin finds (coins that do not belong to a hoard) offers an alternative perspective to consider the presence of Eastern denarii in Germany. These coin finds tend to be stray or isolated but can also represent coins from sites. Their general geographic distribution is in its most basic sense a true reflection of their geographic spread. The density of their distribution also provides a control on the hoard distribution pattern. The two find types can therefore provide a measure onto one another in a way that focus on one single find type cannot reveal.

In total, 508 non-hoarded coins struck at Rome (283) or the East (225) between AD 193 and 196/7 have been recorded in Germany. The near-equal balance between the two is particularly noteworthy since hoards reveal that Eastern denarii may only have arrived to the study-region in two batches, indicating that when the coins did arrive, they did so in great quantities.

The distribution of the denarii is also 


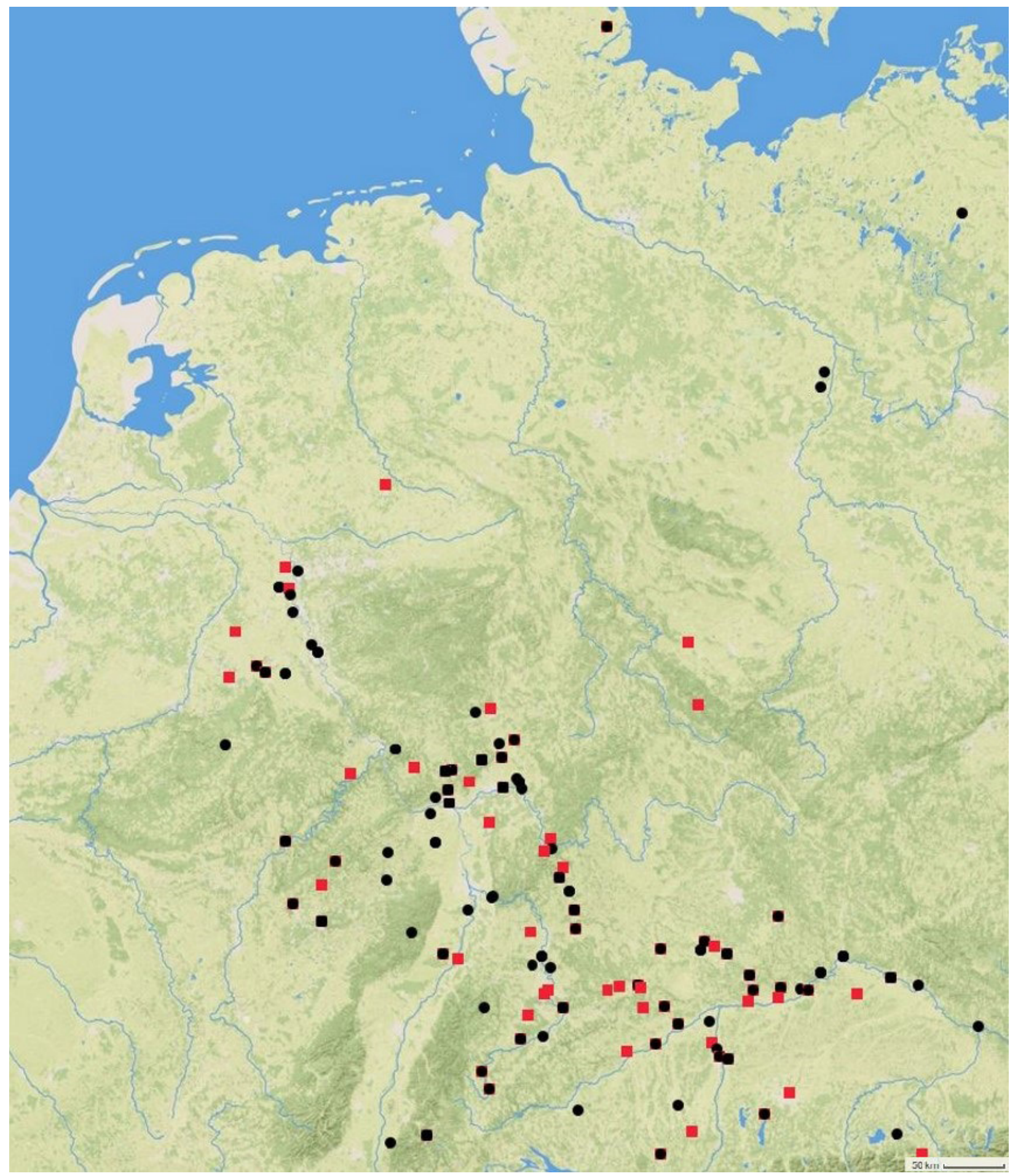

Figure 4. Distribution of non-hoarded Eastern (red square) and Rome (black circle) denarii AD 193-196/7 in Germany

telling. All the denarii struck between AD 193 and 196/7, irrespective of their mint are found nearby one another, principally nearby the limes. Two different densities of the number of find spots also occur - a northern less dense area and a more southern, dense, and large distribution area (Fig. 4). When we compare this distribution to that of the hoards (Fig. 5), we can better interpret the non-hoarded coin find distribution pattern.

\section{FUNCTION, PURPOSE, AND} HISTORICAL TIES

The graphs and figures above demonstrate that Eastern denarii were hoarded in two peak periods. The first around AD 235 and the second around AD 248-253. 


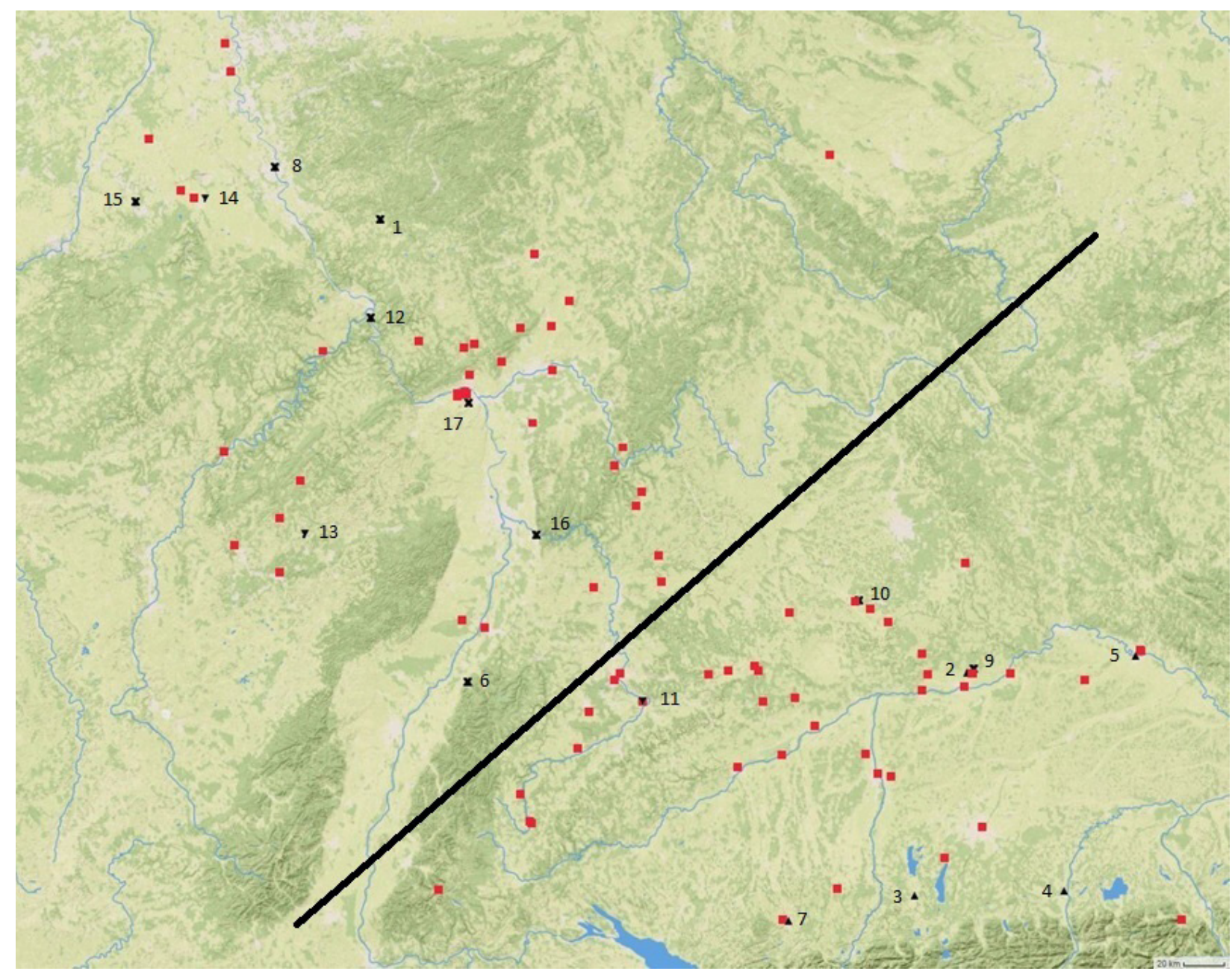

Figure 5. Distribution of non-hoarded Eastern denarii struck AD 193-196/7 (red square) and hoards with minimum 10 denarii issued AD 193-196/7 (Triangle Up: 230-236; Triangle Down: 248-253; Cross: Other TPQ)(Appendix 1 for hoard numbers).

If the hoards are representative of circulation, we may obverse that the first 'batch' of Eastern denarii arrived in the early 230s and were mostly removed from the available circulating coin-pool by AD 236. Their distribution was predominately in vicinity of the Upper Danube where a dense clustering of coins from AD 193196/7 occurs (Fig. 4). The second 'batch' of Eastern denarii is likely to have arrived in the mid-240s and mainly been withdrawn from the coin pool by AD 253. This distribution is slightly more dispersed but certainly sees a shift towards the northwest, along the Rhine. In fact, a broad-brush impression of the shift is obtained through all the hoards with the earlier TPQ hoards predominantly confined to the southern German Danube area, and the later hoards to the Rhine area (Fig. 5).

A historical explanation could be provided to explain the find pattern behind the Eastern denarii in Germany. The first peak of Eastern denarii in hoards occurs around AD 235, with the first Eastern denarii in hoards occurring in AD 231. This coincides with a number of Germanic attacks in the early 230s, although Drinkwater suggests that the extent of these should not be exaggerated. ${ }^{13}$ Nevertheless, the geographic and chronologic clustering of hoards and non-hoarded Eastern denarii along more southern limes area of Germany does help substantiate Herodian's record that Germans had crossed the Danube and were posing a threat to Italy. ${ }^{14}$ The prominent 'emergence' of Eastern denarii in hoards certainly signals the possibility that a considerable injection of these coins occurred

13 DRINKWATER 2005, 29.

14 HERODIAN 6.7.2; OKAMURA 1984, 190. 
rapidly since very few Eastern denarii are found in any hoards with a TPQ earlier than the AD 230s (regardless of a minimum threshold).

Linking the coin injection to any Germanic group is difficult, since the Alamanni, Hermunduri, and Chatti have all been suggested as possibilities. ${ }^{15}$ Similarly, others have attempted to trace the movement of troops during this period as there are indications of broad troop (re-)deployment from the East to the West. Dabrowa has argued for the movement of Legio III Gallica from Persia (active AD 231-4) to the Danube and linked a vexillatio of Legio X Frentensis as one group of soldiers redeployed from the East to the German limes during this time. ${ }^{16}$ Legio XXX U.V. may also have been responsible for the influx of coin, since we know that several units served with Severus Alexander in the East before the stalemate with Ardashir in the East, and both Severus and the legion are recorded to have traveled to the German limes in $\mathrm{AD} 234 .^{17}$

This spur of activity seems to have been followed by a decade of relative calm during which hoards indicate that less Eastern denarii were circulating. During this period, a slow shift northward of hoards by TPQ is also discernable, but above all, it coincides with an apparent increase in the number of available Eastern denarii (if hoards are considered representative of the available coin pool). Once again, it is difficult to offer a precise link or explanation for the observed hoarding pattern despite the distinct geographic separation between two different periods of hoarding. Although we are aware that both Gordian III and Philip I were forced to deal with the Goths along the Lower Danube a shift north away from the Danube cannot be related to activities against the Goths. It is plausible, however, that the celebrated title

\footnotetext{
15 OKAMURA 1984, 191; DRINKWATER 2007, 51; Wolfram 2005, 41; VON PETRIKOVITS 1981, 382; WILKES 2005, 223; CHRISTLEIN 1978, 22-3.

16 DABROWA 1998a, 311-312; DABROWA 1998b, 321.

17 Campbell 2005, 26.
}

of 'Germanici Maximi' by Philip I and his son may refer to the Germanic tribes along the Rhine. ${ }^{18}$ If we can make the link between peak hoarding and Germanic troubles, it seems to have ended shortly after Gallienus moved his residence to Cologne in $\mathrm{AD} 253$ and remained there for several years. ${ }^{19}$ The origin of Eastern denarii during this second hoarding peak is unclear but it may be related to the first batch, if we make the tenuous link between Gallienus' residency as well as involvement of Legio XXX U.V during his reign to counter the new incursions of the Francs and Alamanni.

\section{CONCLUSION}

This paper has compared the hoard profile of Septimius Severus' Eastern denarii struck between AD 193 and 196/7, in Roman Germany, in order to understand when, how, and why these coins travelled so far from their place of origin. Comparing the German hoard profile to the established pattern in Britain suggests that we should not regard the profile as a manifestation of Gresham's Law, as Duncan-Jones argued, but rather that the find pattern is highly regionalized and unique, to the point where even within a relatively limited geographical area along the German limes, two distinct hoarding phases are visible.

The distribution of non-hoarded coins, especially the Eastern denarii struck AD 193$196 / 7$, allows us to obtain a clear picture of the full geographic coverage of these coins within the entirety of Germany. Notably, very few of these coins travelled into the hinterland away from the limes, and even less beyond the border into germania magna. The agglomeration of non-hoarded coins around the limes further corroborates the interpretation of hoards and allows us to seek historical explanations for behind their confined chronology and geographic distribution.

When we consider the coin find profile from Germany together with the British hoard profile, established by Howgego, the difference

18 OKAMURA 1984, 218; LORIOT 1975, 792; SCHMIDT 1940, 12; ROEREN 1960, 217.

19 WILKES 2005, 222. 
Table 1. Non-Hoarded denarii by 'mint' struck AD 193-196/7, by region.

\begin{tabular}{lccc}
\hline Area & Eastern & Rome & East as \% of total \\
\hline Germany & 225 & 283 & $44.3 \%$ \\
\hline Germany, Luxembourg, The Netherlands & 252 & 376 & $40.1 \%$ \\
\hline Luxembourg, The Netherlands & 27 & 93 & $22.5 \%$ \\
\hline
\end{tabular}

between the two suggests that there could be different explanations for their arrival to each area. For the German limes area, broad historical accounts were sought to clarify the overall arrival of Eastern denarii to the area but also to justify differences within the studied area. In this case, two known periods of Germanic incursions in two separate areas along the limes, coincided with the direct involvement of the emperor and troop transfers from the East, perhaps explaining the arrival and/or hoarding pattern of Eastern denarii. Whatever their arrival means, it is clear that the Eastern denarii are found in a relatively confined area since there is a considerably lower proportion of non-hoarded Eastern denarii in Luxembourg and The Netherlands compared to Germany (Table 1).

Explaining the disparate pattern in Roman Britain is a bit more problematic. Howgego understands the hoards to represent some sort of arrival and mixture of coins through taxes and rents, or trade, or the movement of military personnel. ${ }^{20}$ The first options are difficult to demonstrate or prove. The latter, movement of military personnel, may be related to military activity in the German limes area especially since no early TPQ hoards in Britain contain any Eastern denarii struck AD 193-196/7 and the curve only increases from AD 230 (Fig. 3 ), the first peak period in Roman Germany. Correspondingly, in Britain, there is also a gap in hoard TPQs with sufficient Eastern denarii, between the mid-230s and $\mathrm{AD} 248$, before two late hoards close consisting of the highest proportion of Eastern denarii. ${ }^{21}$ We know of troop movement under Gallienus between Britain and Germany in AD 254 so these

\footnotetext{
20 HOWGEGO 1996, 224.

${ }^{21}$ HOWGEGO 1996, 225.
}

later hoards may be related, should certain contingents have returned to the island. ${ }^{22}$ Again, the evidence is at best tentative but it does try to explain the distinct patterns between two neighboring provinces. An interpretation of taxes and rents, or trade is a bit harder to support due to a lack of evidence and, more problematic, how a process of mixing could produce such erratic patterns.

One should not, however, casually link hoards and coin finds with military activity but the third century is characterized by the rising cost of war and defense of the limes. The increasing cost had an obvious impact on the economy with the military budget accounting for the vast majority of state expenditure, especially with increasingly frequent pay rises alongside debasement. With the mobilization of vast resources to maintain the overextended Empire, we cannot rule out a possible direct 'cash injection' into the German economy to offer short-term relief in order to make payments, an account that does not exclusively rely on significant troop transfer to explain the presence of Eastern denarii struck AD 193-196/7 along the German limes. ${ }^{23}$

\section{REFERENCES}

\section{BUTCHER 2004}

Butcher, K. Coinage in Roman Syria. Northern Syria, $64 B C-A D$ 253. London, 2004.

\section{CAMPBELL 2005}

Campbell, B. 'The Severan dynasty', in The Cambridge Ancient History. Volume XII: The Crisis of Empire, A.D. 193-337. Second 22 WILKES 2005, 222.

23 This possibility would need to be substantiated by large groups of coins with a limited geographic distribution - possibly other Eastern denarii that show similar hoarding patterns but are not severely impacted by debasement. 
Edition. Eds. A. K. Bowman, P. Garnsey, and A. Cameron. Cambridge, 2005, pp. 1-27.

\section{CHRISTLEIN 1978}

Christlein, R. Die Alamannen. Stuttgart, 1978.

DABROWA 1998a

Dabrowa, E. 'Legio III Gallica', in Les légions de Rome sous le Haut-Empire. Actes du Congrès de Lyon 17-19 Septembre 1998. Eds. Y. Le Bohec and C. Wolff. Paris, 1998a, pp. 309-316.

DABROWA 1998b

Dabrowa, E. 'Legio X Frentensis', in Les légions de Rome sous le Haut-Empire. Actes du Congrès de Lyon 17-19 Septembre 1998. Eds. Y. Le Bohec and C. Wolff. Paris, 1998b, pp. 317-326.

\section{DRINKWATER 2005}

Drinkwater, J. F. 'Maximinus to Diocletian and the 'crisis", in A. Bowman, A. Cameron, and P. Garnsey (Eds.), The Cambridge Ancient History Volume 12: The Crisis of Empire, AD 193-337. Second Edition. Eds.

A. K. Bowman, P. Garnsey, and A. Cameron. Cambridge, 2005, pp. 28-66.

\section{DRINKWATER 2007}

Drinkwater, J. F. The Alamanni and Rome 213-496. Caracalla to Clovis. Oxford, 2007.

HOWGEGO 1996

Howgego, C. 'The circulation of silver coins, models of the Roman economy and crisis in the third century A.D.: some numismatic evidence', in Coin Finds and Coin Use in the Roman World. Eds. C. E. King and D. G. Wigg. Berlin, 1996, pp. 219-236.

HOWGEGO 2002

Howgego, C. "The Denarii of Septimius Severus and the Mobility of Roman Coin: A Reply', in Numismatic Chronicle 162, pp. 339-42.

\section{DUNCAN-JONES 1994}

Duncan-Jones, R. Money and Government in the Roman Empire. Cambridge, 1994.

DUNCAN-JONES 2001

Duncan-Jones, R. 'The Denarii of Septimius Severus and the Mobility of Roman Coin', in Numismatic Chronicle 161, pp. 75-89.

DUNCAN-JONES 2002
Duncan-Jones, R. 'The Denarii of Septimius Severus and the Mobility of Roman Coin: Further Comment', in Numismatic Chronicle 162, pp. 342-345.

\section{FMRD}

H. Gebhart, K. Kraft et al. (eds.), Die Fundmünzen der römischen Zeit in

Deutschland. Berlin, 1960-2011.

HELLINGS/SPOERRI BUTCHER 2017

Hellings, B. D. R. and M. Spoerri Butcher, 'Quantifying relative coin production during the reigns of Nerva and Trajan (AD 96-117): Reka Devnia reconsidered in light of regional coin finds from Romania and the northwest', in Revue belge de Numismatique et de Sigillographie 163, pp. 53-86.

HELLINGS 2018

Hellings, B. D. R. 'Quantifying relative aureus production during the mid-first century in light of coin finds from the northwest', in Revue belge de Numismatique et de Sigillographie 164, pp. 382-425.

\section{LORIOT 1975}

Loriot, X. 'Chronologie du regne de Philippe l'Arabe (244-249 après J.-C.)', in Aufstieg und Niedergang der römischen Welt II, 2, pp. 788-797.

MATTINGLY/SYDENHAM 1936

Mattingy, H. and E. A. Sydenham, The Roman Imperial Coinage. Vol. IV. Part I. Pertinax to Geta. London, 1936.

\section{OKAMURA 1984}

Okamura, L. Alamannia Devicta: RomanGerman Conflicts From Caracalla to the First Tetrarchy A.D. 213-305. PhD Thesis, University of Michigan, 1984.

\section{VON PETRIKOVITS 1981}

Von Petrikovits, H. 'Chatten', in Reallexikon der germanischen Altertumskunde: 4, Brunnen-Chronologie. Second Edition. Eds. H. Beck, H. Jankuhn, and J. Hoopes. Berlin, 1981, pp. 377-391.

\section{ROEREN 1960}

Roeren, R. 'Zur Archäologie und Geschichte Südwestdeutschlands im 3. bis 5. Jahrhundert n. Chr.', in Jahrbuch des Romisch-Germanischen Zentralmuseums, Mainz 7, pp. 214-294. 
SCHMIDT 1940

Schmidt, L. Geschichte der deutschen Stamme bis zum Ausgang der Volkerwanderung. Die Westgermanen, Munich, 1940.

WILKES 2005

Wilkes, J. 'Provinces and frontiers', in The Cambridge Ancient History. Volume XII:
The Crisis of Empire, A.D. 193-337. Second Edition. Eds. A. K. Bowman, P. Garnsey, and A. Cameron. Cambridge, 2005, pp. 212-568. WOLFRAM 2005

Wolfram, H. The Roman Empire and Its Germanic Peoples, Transl. T. Dunlap. London, 2005.

Appendix 1. Hoards in Germany with a minimum of 10 denarii struck AD 193-196/7

\begin{tabular}{|c|c|c|c|c|c|c|c|}
\hline FMRD & Name & East & Rome & Total & TPQ & $\%$ & Hoard no. Fig 5 \\
\hline $4.5,5028$ & OBERERBACH & 0 & 11 & 11 & 222 & 0 & 1 \\
\hline $1.2,2116$ & KIRCHMATTING & 27 & 73 & 100 & 231 & 27 & 2 \\
\hline $1.1,1325$ & MARNBACH & 5 & 10 & 15 & 235 & 33 & 3 \\
\hline 1.7, 7199 & WIGGENSBACH & 18 & 20 & 38 & 235 & 47 & 4 \\
\hline $2.4,4596$ & WELZHEIM & 66 & 87 & 153 & 235 & 43 & 5 \\
\hline $2.2,2196$ & BADEN-BADEN & 7 & 5 & 12 & 235 & 58 & 6 \\
\hline $1.1,1229$ & NIEDERASCHAU & 11 & 36 & 47 & 236 & 23 & 7 \\
\hline $6.1 .1,3 \mathrm{a}$ & KÖLN & 8 & 36 & 44 & 238 & 18 & 8 \\
\hline $1.1,1115$ & KÖSCHING & 6 & 20 & 26 & 241 & 23 & 9 \\
\hline $1.5,5057$ & GUNZENHAUSEN & 5 & 11 & 16 & 243 & 31 & 10 \\
\hline $2.4 \mathrm{~N} 1,4135 / 1$ & KÖNGEN & 12 & 18 & 30 & 248 & 40 & 11 \\
\hline $4.5,5011$ & NIEDERLAHNSTEIN & 4 & 6 & 10 & 250 & 40 & 12 \\
\hline 3,1082 & WIESBACH & 3 & 27 & 30 & 253 & 10 & 13 \\
\hline $6.2 .1,2024$ & $\begin{array}{l}\text { STADTTEIL } \\
\text { DISTELRATH }\end{array}$ & 21 & 42 & 63 & 253 & 33 & 14 \\
\hline $6.2 .2,2511$ & ORTSTEIL VETSCHAU & 6 & 26 & 32 & 258 & 19 & 15 \\
\hline $2.1,1064$ & $\begin{array}{l}\text { HEIDELBERG- } \\
\text { NEUENHEIM }\end{array}$ & 2 & 8 & 10 & 268 & 20 & 16 \\
\hline $4.1,1164$ & MAINZ & 9 & 13 & 22 & 268 & 41 & 17 \\
\hline
\end{tabular}


